\title{
The Possibilities of Assessing Students' Scientific Inquiry Skills Abilities Using an Online Instrument: A Small-Scale Study in the Omusati Region, Namibia
}

\author{
Linus Kambeyo \\ Doctoral School of Education, University of Szeged, Hungary \\ doi: 10.19044/ejes.v4no2a1 URL:http://dx.doi.org/10.19044/ejes.v4no2a1
}

\begin{abstract}
The objectives of this study were to; explore the possibilities and feasibilities of an online assessment of students' scientific inquiry skills; examine the psychometric properties of the test; ascertain the ability level of the $9^{\text {th }}$ and $11^{\text {th }}$ graders scientific inquiry skills. The sample consisted of the ninth and eleventh graders $(\mathrm{N}=118,44$ boys and 74 girls; age mean $=16.42$, and $(\mathrm{SD})=1.25)$. In the test of scientific inquiry skills, students were required to use their cognitive skills to answer questions based on different subscales of scientific inquiry processes. The online assessment tool for scientific inquiry skills consisted of 99 items. The Cronbach alpha was .87 $\alpha$, and two subscales emerged with better reliability of .93 $\alpha$ and $.90 \alpha$ respectively. No significant differences were found between grades and genders concerning performances. The online assessment instrument for students' scientific inquiry skills proved to be feasible and reliable. The findings indicate that online assessment may provide teachers with an easyto-use instrument for monitoring the development of students' scientific inquiry and reasoning skills. However, for this to be realized in Namibian, the government should try to improve the ICT infrastructures in most public schools as per their blueprint.
\end{abstract}

Keywords: Technology-based assessment; scientific inquiry skills, science education; students' assessment.

\section{Introduction}

This study reports a small-scale study on assessing students' scientific inquiry skills using the online test instrument in Omusati region, Namibia. We live in an ever-changing world - demographic change, rise of automation and workforce structural change, globalization, and corporate change are some major driving forces that demand fundamental transformations in education and skills on an individual level (Bao \& 
Koening, 2012). Of late, many studies have emphasized the importance of technology-based assessment. Namibia being new in the international arena, the technology-based assessment is almost nonexistence. However, there exist a government policy on information communication and technology (ICT) in paper, but the implementation part is lagging behind. Namibia currently has few mechanisms below grade 12 end of school year examination, for measuring the performance of the system against international benchmarks (Ministry of Education, 2007), neither is there any effective mechanism for parents and other stakeholders to judge the performance of individual institutions. The assessments of scientific thinking and critical thinking have not yet been established.

Elsewhere in the world, organizations and research committees, for example, the Organization for Economic Corporation and Development (OECD) are advocating for the notions of critical thinking skills, problem solving skills, and creativity as some major components of the $21^{\text {st }}$ century skills that need to be possessed by $21^{\text {st }}$ century students. Among these, are the science process skills (SPS). The scientific method, scientific thinking and critical thinking are terms that have been used at various times to describe these science skills. These skills are defined as a set of broadly transferable abilities, appropriate to many science disciplines and reflective of the behavior of scientists (Padilla, 1990). The science process skills are grouped into two types; basic and integrated. The basic (simpler) process skills provide a foundation for learning the integrated (more complex) skills. Basic SPS include observations, inferring, measuring, communication, classification and making predictions while integrated SPS consist of controlling of variables, formulating hypotheses, interpreting data, experimenting and formulating models (Padilla, 1990).

In this paper, the terms scientific inquiry, scientific reasoning skills and thinking skills will be used interchangeably to refer to science processes skills needed to be acquired by the students in the $21^{\text {st }}$ century. In his study, Padilla (1990) found that experimenting ability, one of the integrated SPS, is closely related to the formal thinking abilities described by Piaget. Thus, the instrument used is underpinned by Piaget formal thinking operation that students at this level are supposed to have acquired.

At the moment, no empirical data exist in the literature from Namibia about studies on these skills (scientific inquiry, scientific reasoning and general thinking skills, such as inductive reasoning) that are deemed critical in the $21^{\text {st }}$ century. The demands on learners and thus, education systems are evolving fast (Csapó \& Funke, 2017). In the past, education was about teaching people something, now; it is about making sure that students develop a reliable compass and the navigation skills to find their own way through an increasingly uncertain, volatile and ambiguous world. Therefore, 
the purpose of this study was to explore the possibilities and feasibilities of online assessment of scientific inquiry skills, examine the psychometric properties of the test (Scientific inquiry skills test) and ascertain the ability level of the $9^{\text {th }}$ and $11^{\text {th }}$ graders, as well as to examine how the background variables (gender, grade, parents' level of education) affect performances.

\section{Theoretical background}

Scientific inquiry

Scientific inquiry has always been an integral part of scientific literacy (Bybee, 2009). Hence, scientific inquiry has been a long-standing area of research and discussion in science education (Fenichel \& Schweingruber, 2010; Yeh, Jen \& Hsu, 2012). Scientific inquiry is seen as a problem-solving task (Klahr, 2000). It can also be viewed as a circular process, where research questions and hypotheses are formulated, investigations are planned and carried out, and evidence is evaluated with regard to the hypotheses and the underlying theory (Mayer, 2007; Zimmermann, 2005). In order to achieve this circular process, various methodological and cognitive skills are inevitably important. Gott and Duggan (1998, p. 95), for example, mentioned the following skills that are needed to do science: 'generate own ideas, hypotheses and theoretical models or utilize those postulated by others; design and conduct experiments, trials, test, simulations and operations; and evaluate the resulting data'. These skills can further be divided into cognitive skills, i.e. generate hypotheses, and methodological skills, i.e. conduct an experiment. These definitions also resonates well with the (American Association for the Advancement of Science \{AAAS\}, 1993) which asserts, "Scientific inquiry is more complex than popular conceptions would have it. It is, for instance, a more subtle and demanding process than the naive idea of 'making a great many careful observations and then organizing them.' It is far more flexible than the rigid sequence of steps commonly depicted in textbooks as 'the scientific method.' It is much more than just 'doing experiments,' and it is not confined to laboratories. More imagination and inventiveness are involved in scientific inquiry than many people realize, yet eventually strict logic and empirical evidence must have their day. Individual investigators working alone sometimes make great discoveries, but the steady advancement of science depends on the enterprise as a whole” (p. 9).

To implement these aspects of scientific inquiry in school, governments worldwide have set standards or benchmarks for science education. These documents, although each nation has its own, have some common aspects concerning scientific inquiry (National Research Council, 1996). These standards forms a conceptual framework for teaching science. They include more detailed standards and objectives for each subject (for 
biology/life science, and physical science \{chemistry and physics\}) that specify which aspects should be taught in the biology or in the physical science class (Bybee, 2009). In Namibia, the aims and objectives of the National syllabus for sciences are the same across. "Learning experiences in the natural scientific area aim at increasing the learners' knowledge and understanding of the physical and biological world of which they are part. This includes understanding how people use the natural environment to satisfy human needs, and how the environment may be changed in ecologically sustainable ways. Critical thinking, investigating phenomena, interpreting data, and applying knowledge to practical (experimental and investigative) skills and abilities are essential to understanding the value and limitations of natural scientific knowledge and methods, and their application to daily life" (Ministry of Education (MoE)., 2010, p. 2). The application of scientific knowledge and attitudes to health is of special relevance for the individual, the family and society as a whole. These set standards foregrounded scientific inquiry as one area of competence for the three science subjects. For each of these subjects, there is a description of scientific inquiry and some examples of which aspects should be taught.

The methods used for scientific investigations play an important part in scientific inquiry. Mayer (2007) mentions the following methods: observing, investigating, describing, comparing, classifying, experimenting and using models. These descriptions are similar to what is in the national syllabi for science subjects in Namibia. It also resonates well with what is in the national broad curriculum of education in Namibia and the country's Vision 2030, which sees Namibia as "developing from a literate society to a knowledge-based society, a society where knowledge is constantly being acquired and renewed, and used for innovation to improve the quality of life. A knowledge-based society requires people who are healthy, well educated, skilled, pro-active, and with a broad range of abilities" (MoE, 2009). Zimmerman (2005) describes activities for scientific investigations such as designing experiments, using apparatus and observing. Models can be used as an instrument for scientific investigations. Gilbert, Pietrocola, Zylbersztajn, \& Franco (2000) claim that models and modelling should have a major impact on the learning of science in school.

\section{Scientific reasoning and scientific inquiry}

Scientific reasoning is one major components of scientific inquiry, as it contains thinking and reasoning skills (Zimmerman, 2005). Mayer (2007) describes scientific reasoning with the following processes: formulating scientific questions, generating hypotheses, planning investigations, analyzing data and making conclusions. Klahr (2000) on the other hand, describes scientific reasoning as a process of dual search, which includes 
searching the 'hypothesis space' and the 'experiment space'. The 'evidence evaluation process' (Klahr 2000) mediates the two steps. Zimmerman (2005) describes it using similar aspects such as, asking questions, hypothesizing, recording and interpreting data. From their definition, three main process of scientific inquiry emerged. Three main processes are central to scientific reasoning: asking questions and formulating hypotheses, planning and performing an investigation, and analyzing data and reflecting on the investigation (Nowak, Nehring, Tiemann \& Upmeier zu Belzen, 2013). Under these three main processes, many different skills of scientific inquiry can be found.

Furthermore, scientific inquiry is the way that natural scientists try to answer scientific questions. Scientific inquiry processes can be described as a problem-solving task (Klahr, 2000). As alluded to earlier, it is a circular process, in which questions are asked, investigations are carried out and evidence is evaluated (Mayer, 2007; Zimmerman, 2005). However, other researchers found that scientific inquiry is not a homogeneous construct (Lederman and Lederman, 2012). It consists of a variety of different processes such as methodological and cognitive skills. To be scientifically literate, one needs to understand how scientist work. Studies have shown that students have difficulties in thinking and working scientifically (Gott and Duggan, 1998; Klahr, 2000; Zimmerman, 2005).

Previous studies about scientific inquiry have focused on specific subject (Mayer, 2007), on one inquiry method (Hammann, Phan, Ehmer \& Grimm, 2008), or on cognitive (Klahr, 2000) or practical aspects of scientific inquiry (Gott and Duggan, 1995). Other studies on scientific inquiry were about views and perceptions of either students or teachers towards scientific inquiry (Gaigher, Lederman \& Lederman, 2014; Schwartz, Lederman \& Lederman, 2008; Senler, 2015). Furthermore, many research studies on inquiry skills appeared to be dominated by a focus on classroom-based science investigations (Capps \& Crawford, 2013; NRC, 2012). Chinn and Malhotra (2002) found that 'many scientific inquiry tasks given to students in schools do not reflect the core attributes of authentic scientific reasoning' (p. 176), and suggest that inquiry tasks should go beyond hands-on activities to also include evaluation of evidence, complex data and simulations. Additionally, most of the studies were conducted in the European or Asian countries. In this study however, these different aspects, which could influence students' abilities, are taken into account and the focus in this study is not on a specific subject but on general inquiry skills concerning science. Hence, during the tasks formulation the focus was on scientific reasoning using the inquiry skills test. The assumptions was that students should have acquired sufficient level of inquiry skills from all their science lessons i.e. from the $5^{\text {th }}$ grade through the $11^{\text {th }}$ grade. Both cognitive 
(scientific reasoning) and practical skills of scientific inquiry were considered. To achieve these goals, a theoretical structure of scientific inquiry was developed that includes cognitive (scientific reasoning) and practical aspects (inquiry methods) applicable in the science education. Based on these, an online test items were developed to assess students' performance and abilities in scientific thinking.

\section{Research Aim and objectives}

The aim of this study was to pilot the on-line diagnostic instrument for the assessment of scientific inquiry skills using the cognitive skills (scientific reasoning skills) of the $9^{\text {th }}$ and $11^{\text {th }}$ graders. This study seeks to answer the following specific questions;

1. What are the psychometric properties of the scientific inquiry skills?

2. Is there statistical significant difference in performance between grades, gender and parents' level of education of students?

3. What is the ability and development level of students' scientific inquiry skills?

\section{Methods}

Participants

The sample of the study was drawn from a secondary school in Omusati region, northern part of Namibia. The school has grade 8 to 12, and accommodates students from nearby villages and around the whole northern part of Namibia. It is a multicultural (grammar) schools. Participants were the ninth and eleventh graders $(\mathrm{N}=118,44$ boys and 74 girls; age mean $=16.42$, and standard deviation $=1.25$. Forty-one students were grade $9 \mathrm{~s}$ (17 boys and 24 girls), age mean=15.10; standard deviation=.67. The 77 students were eleventh graders (boys $=27$ and girls $=50$, age mean $=17.13$, standard deviation=.85). The school has a hostel (dormitory), and all the learners were accommodated in the school hostel at the time of the study. Table 1, showing the distribution of sample and their parents' level of education.

\section{Instrument}

This study was based on a test of scientific inquiry skills, where students are required to use their cognitive skills (scientific reasoning skills) to answer questions based on different sub construct of scientific processes.

The Hungarian based scientific inquiry skills test was adapted and used in the Namibian science context. The test is developed by the Magyar Tudomanyos Akademia (MTA) - research group of the Institute of education, University of Szeged, to assess Hungarian students' scientific 
inquiry skills. Items were developed based on (Wenning, 2007) scientific inquiry skills framework model. The Wenning (2007) model was simplified to accommodate the basic skills required in the general school science curricula.(Nagy, Korom, Pásztor, Veres, \& Németh, 2015), designed a simplified model that consist of seven sub constructs. The sub constructs are; data handling technique, identification of variables, setting research questions, hypothesis formulation, variable planning, and experimental plans and making conclusions. Tasks require students to apply their reasoning skills and recall the experiments/practical work/ investigations project they have done at school from grade 8 to 12. Since the tasks were developed in Hungarian context, a professional translator, (Molnar Edit) with, the help of people that are involved in the task development did texts translation from Hungarian to English. Tasks that were deemed not fitting in the Namibian scence context were removed and some were adapted. The online assessment tool for scientific inquiry skills consisted of 38 tasks with 99 items. Figure one and two show sample task from data handling construct and hypothesis formulation respectively.

\section{Validation of the research instrument}

In order to develop valid items for these scales, the author conducted content analysis of the science syllabi for grade 8-12 curriculum. A thorough study and comparing if the items content fit into the Namibian science curriculum was done. The test was also sent to the Chief Science Education officer at the curriculum development centre in Namibia, National Institute for Educational Development (NIED). Furthermore, two science education lecturers from the University of Namibia and three experienced teachers in science subjects were also asked to check the contents and the questions of the instrument. Their suggestions were positive and strong suggestion to improve the language was given. Tasks that were context/cultural embedded were replaced with the non-contextual tasks. However, science being a universal subject there were not many cultural embedded items, reviewees were looking forward to see how the students would perform. 
It was raining a lot in the previous days. On the first day $10 \mathrm{~mm}$ rain fell, on the second day $15 \mathrm{~mm}$, on the third day $20 \mathrm{~mm}$ and on the fourth day $40 \mathrm{~mm}$ of rain fell. Which diagram shows correctly the changes of rainfall? Click on it.
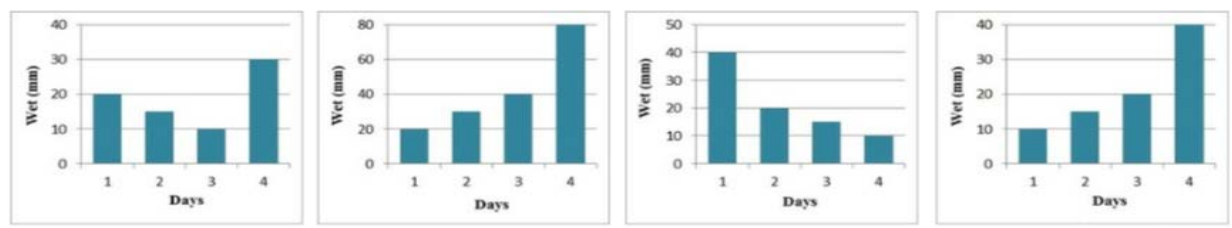

- Previous

Next 0

Figure 1. Sample item; Data handling (Nagy et al., 2015)

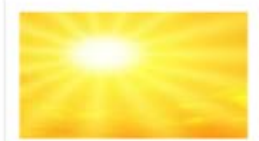

Ndeshi decided to examine whether object with different colors absorb heat from the sun at the same rate. She poured equal amount of water into five identical glass cups. She covered the cups with the same plastic foil in different colours, black, red, blue, and white, but one glass cup was not covered. She arranged the cups so that same amount of sunlight reached each of them. After one hour, she measured the temperature of water in each cup.

Which of the following hypotheses did she test? Click on the right answer.

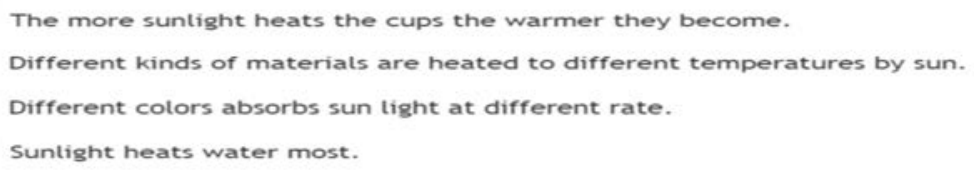

Figure 2. Sample item; Hypothesis formulation (Nagy et al., 2015)

\section{Procedures}

The online data collection was carried out through the eDia (Csapo, Lorincz, Molnar, 2012) platform in January 2017, via internet in the school's information communication technology (ICT) room. Each participants was assigned a number (participants ID) to log into the eDia system, after which the system interface displayed the instructions that students need to follow. Students entered their responses through the keyboard, choosing the right answer by clicking or by dragging and dropping figures on the screen with a mouse. The administration of the test took approximately 135 minutes. 


\section{Results and discussions}

The psychometric properties and testing applicability

The reliability at the whole scale .87 Cronbach alpha, see table 1 , was high, and two subscales with a better reliability of .93 and .90 respectively. However, the remaining five subscales reliability need improvement as their reliabilities stand at $>.50$ Cronbach alpha. The range of scores on the pilot test was 27 to 87 out of 99 possible answers. The test mean was 53.52 (54.10\%) with a standard deviation of 11.31 and a standard error of measurement of 1.04. Our Cronbach alpha, almost matches the inquiry literacy test by (Wenning, 2007), when it was first piloted, (.88 $\alpha$ ).

Table 1, show the reliability at a whole scale and subscales.

(RQs= Research questions)

Table 2, presents the correlation matrix showing bivariate relationships between the variables and the whole scale. Moderate correlations were found among the subscales. Strong correlations between the whole test and subscales was found. However, no significant correlation was found between experimental plans and data handling, experimental plans and identification of variables as well as experimental plans and hypothesis formulation. Therefore, further improvement on the organizing of items into appropriate subscale is needed in order to yield strong correlations between the subscales and to improve the reliability coefficients at the subscales level. A point to note is that at the whole scale level, there are strong positive correlations with the subscales and the internal consistency coefficient is reliably high.

Table 2, Correlations coefficients between 7 sub scales and the whole test.

\begin{tabular}{lllllllll}
\hline & $\mathbf{1}$ & $\mathbf{2}$ & $\mathbf{3}$ & $\mathbf{4}$ & $\mathbf{5}$ & $\mathbf{6}$ & $\mathbf{7}$ & $\mathbf{8}$ \\
\hline 1. Data handling & 1 & & & & & & & \\
2. Identify variables & $.28^{* *}$ & 1 & & & & & \\
3. RQs formulation & $.38^{* *}$ & $.44^{* *}$ & 1 & & & & \\
4. Hypothesis formulation & $.44^{* *}$ & $.18^{*}$ & $.34^{* *}$ & 1 & & & \\
5.Planning of variables & $.45^{* *}$ & $.45^{* *}$ & $.44^{* *}$ & $.36^{* *}$ & 1 & & & \\
6. experimental plans & .17 & $.24^{* *}$ & $.24^{* *}$ & .11 & $.36^{* *}$ & 1 & & \\
7. Making conclusions & $.43^{* *}$ & $.31^{* *}$ & $.37^{* *}$ & $.22^{*}$ & $.40^{* *}$ & $.22^{*}$ & 1 & \\
8. Total scores & $.68^{* *}$ & $.62^{* *}$ & $.68^{* *}$ & $.56^{* *}$ & $.51^{* *}$ & $51^{* *}$ & $67^{* *}$ & 1 \\
\hline
\end{tabular}

${ }^{* *}$ Correlation is significant at $\mathrm{p}<.01$

${ }^{*}$ Correlation is significant at $\mathrm{p}<.05$ 
The relationships between the independent variables and the seven subscales was further explored through multiple linear regression analysis. Table 3 displays a summary of linear enter regression analysis for independent variables (all seven subscales) predicting scientific inquiry. Among the predictors, planning of variables contributed more to the scientific inquiry, with $28 \%$ of explained variances while the remaining six variables contributed moderately with $<26 \%$ explained variances.

Table 3. Summary of multiple linear regression analysis for independent variables predicting scientific inquiry skills with enter statistics

\begin{tabular}{l|l}
\hline Independent variables & Beta \\
\hline Data Handling & $.171^{*}$ \\
Identification of variables & $.206^{*}$ \\
RQ formulation & $.214^{*}$ \\
Hypotheses formulation & $.184^{*}$ \\
Planning of variables & $.275^{*}$ \\
Experimental plans & $.198^{*}$ \\
Making conclusions & $.247^{*}$ \\
\hline
\end{tabular}

Dependent variable: Scientific inquiry, $\left({ }^{*} \mathrm{p}<.05\right), \mathrm{RQ}=$ research question.

\section{Grades and gender differences}

No significant differences were found between grades and genders concerning performances (see Tables 4 and 5 as well as figure 3 and 4). The internal consistency in each grade proved to be highly reliable in terms of the whole scale. Interestingly, grade 9 students performed better in terms of simple mean percentage (see table 4 and figure 3 ). This may mean that the teaching and learning of science at grade 11 focus more on examination than enhancing and incorporating the inquiry methods.

\section{Grades}

\begin{tabular}{lll|lll}
\hline \hline \multicolumn{2}{l|}{ GRADE 9 (N=41) } & \multicolumn{4}{l}{ GRADE 11 (N=77) } \\
\hline Cronbach's $\alpha$ & Mean (\%) & SD (\%) & Cronbach's $\alpha$ & Mean(\%) & SD (\%) \\
\hline .89 & 34.32 & 9.17 & .86 & 32.25 & .96 \\
\hline
\end{tabular}

Table 4, shows the grade mean difference

\begin{tabular}{|c|c|c|c|c|c|c|}
\hline & $\begin{array}{l}\text { No. of } \\
\text { items }\end{array}$ & Cronbach $\alpha$ & Mean \% & SD \% & Min & Max \\
\hline Scientific inquiry skills & 57 & .87 & 33.00 & 9.00 & 14 & 55 \\
\hline Data handling & 9 & .51 & 7.00 & 1.65 & 2 & 9 \\
\hline Identify variables & 6 & .53 & 3.00 & 2.00 & 0 & 6 \\
\hline RQs formulation & 8 & .44 & 5.17 & 1.65 & 1 & 8 \\
\hline Hypothesis formulation & 9 & .50 & 6.21 & 1.65 & 0 & 9 \\
\hline Planning of variables & 8 & .90 & 1.74 & 2.54 & 0 & 8 \\
\hline Experimental plans & 4 & .93 & 1.92 & 1.81 & 0 & 4 \\
\hline Making-conclusions & 13 & .60 & 8.37 & 2.40 & 3 & 13 \\
\hline
\end{tabular}




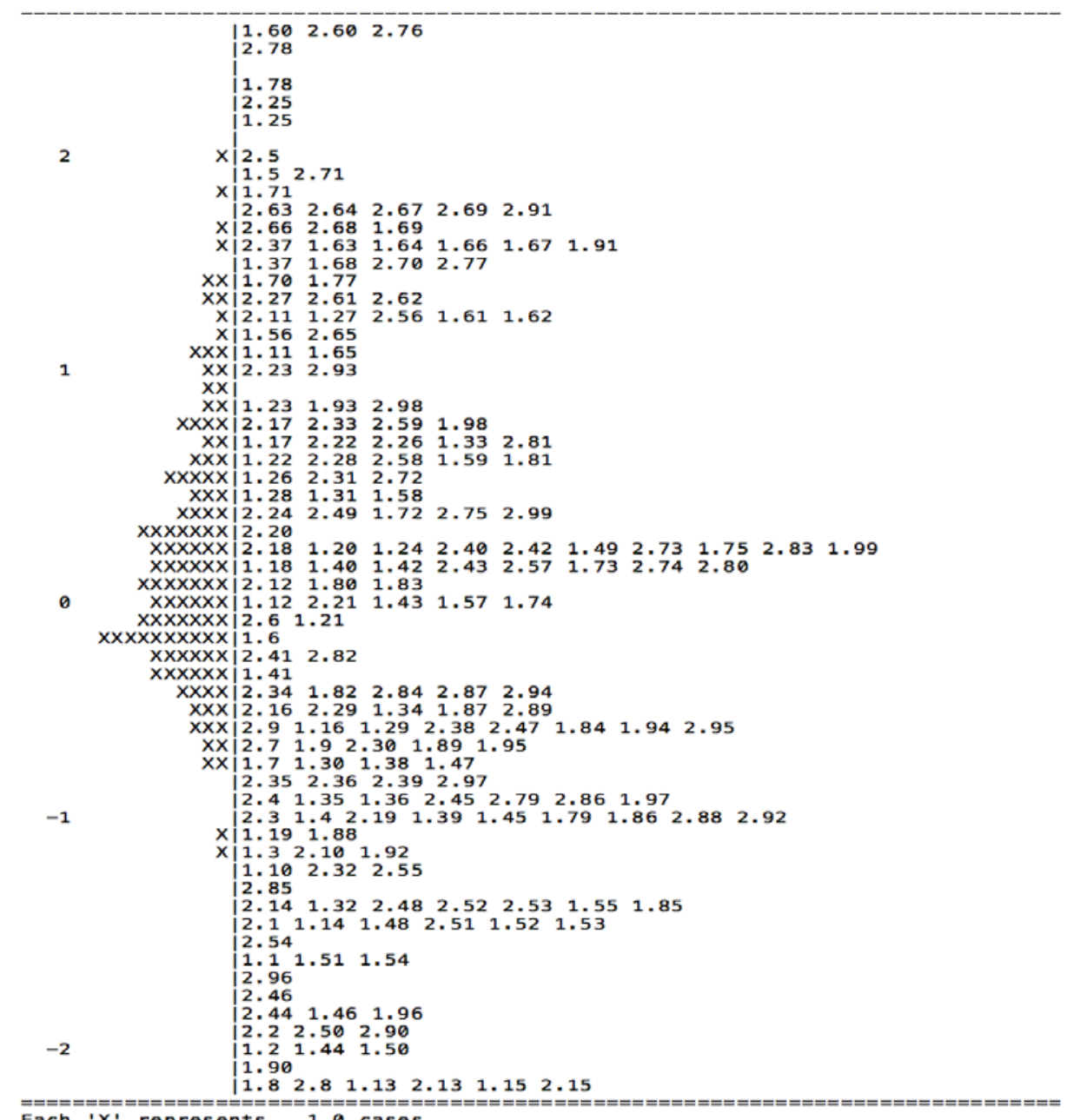
Each ' $X$ ' represents 1.0 cases

Figure 3, shows the grades performance on each item

\section{Gender}

\begin{tabular}{|c|c|c|c|}
\hline \multicolumn{2}{|l|}{ Boys $(\mathrm{N}=44)$} & \multicolumn{2}{|l|}{ Girls $(\mathrm{N}=74)$} \\
\hline Mean (\%) & SD (\%) & Mean(\%) & SD (\%) \\
\hline 31.52 & 7.53 & 33.82 & 9.30 \\
\hline
\end{tabular}

Table 5. Shows the gender mean difference 


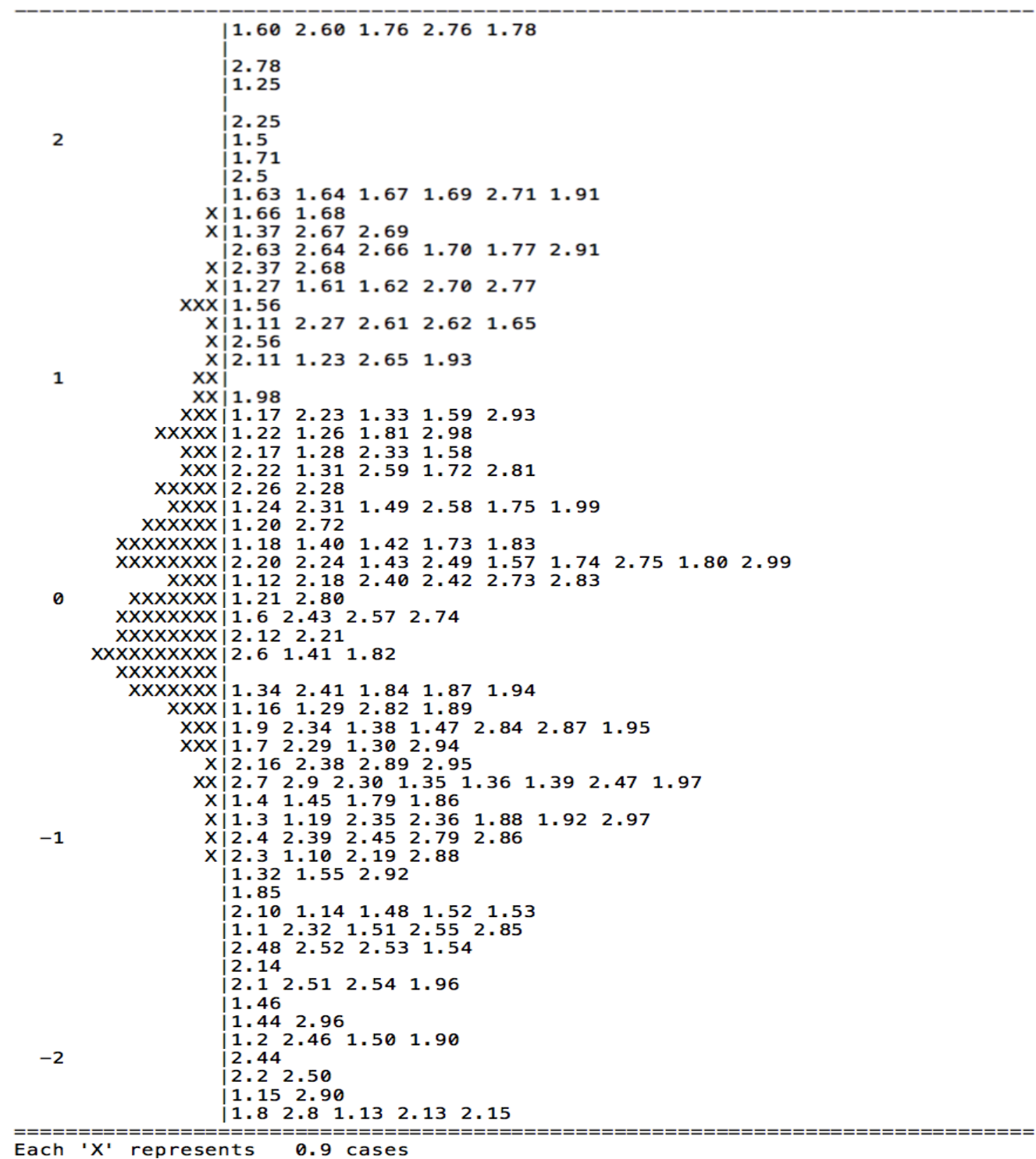

Each ' $X$ ' represents 0.9 cases

Figure 4. shows the gender performance on each item

\section{Students' ability level}

The person item map (Figure 5), indicates that the test is good to measure these cohorts of students in the region. However, further study need to be carried out with large sample for the results to be more generalizable. The distribution is normal, and more students could answer the test items with a probability of more than $50 \%$. Fewer students would also answer all the items with easy and could score $100 \%$. Item 60, 76 and 78 seems to be very difficult for the students (see Figures 3, figure 4 and figure 5), and a thorough review of these items is required. 
high performance

difficult

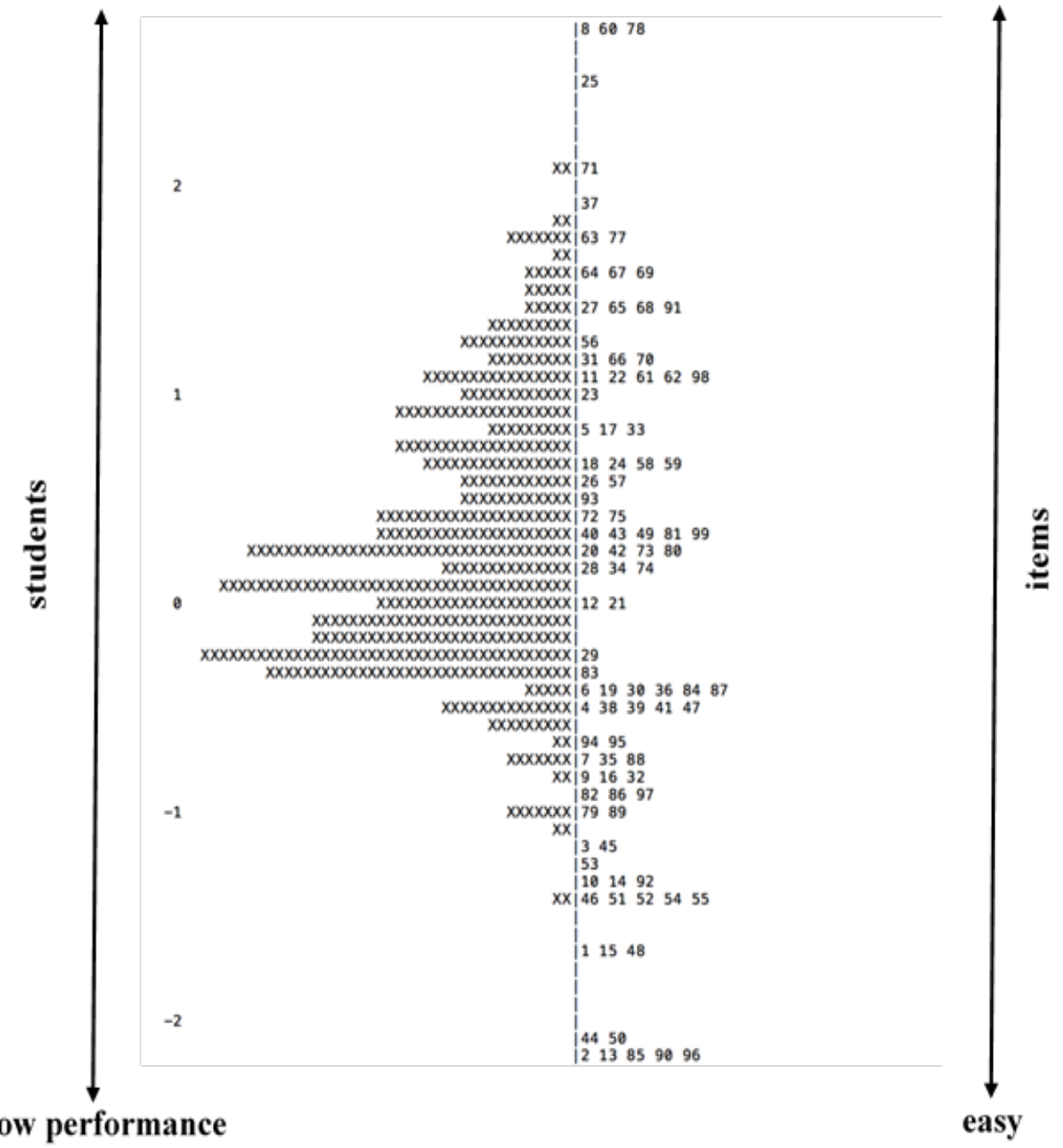

Figure 5. shows the person item map

With regard to the ability level (Figure 6), the interesting finding is that $9^{\text {th }}$ graders (Mean ability difference of .22) has more ability level in answering the test correctly than the $11^{\text {th }}$ graders. This may mean that the teaching and learning at grade 11, focus more on examination than enhancing and incorporating the inquiry methods in the teaching. Of late, our education system has become an examination-oriented, where passing examinations especially in the externally examined grades (grades 10 and 12) is the only benchmark for performance because there is less monitoring of learning achievements at other levels within the education cycle (Simasiku, Kasanda \& Smit, 2015). 


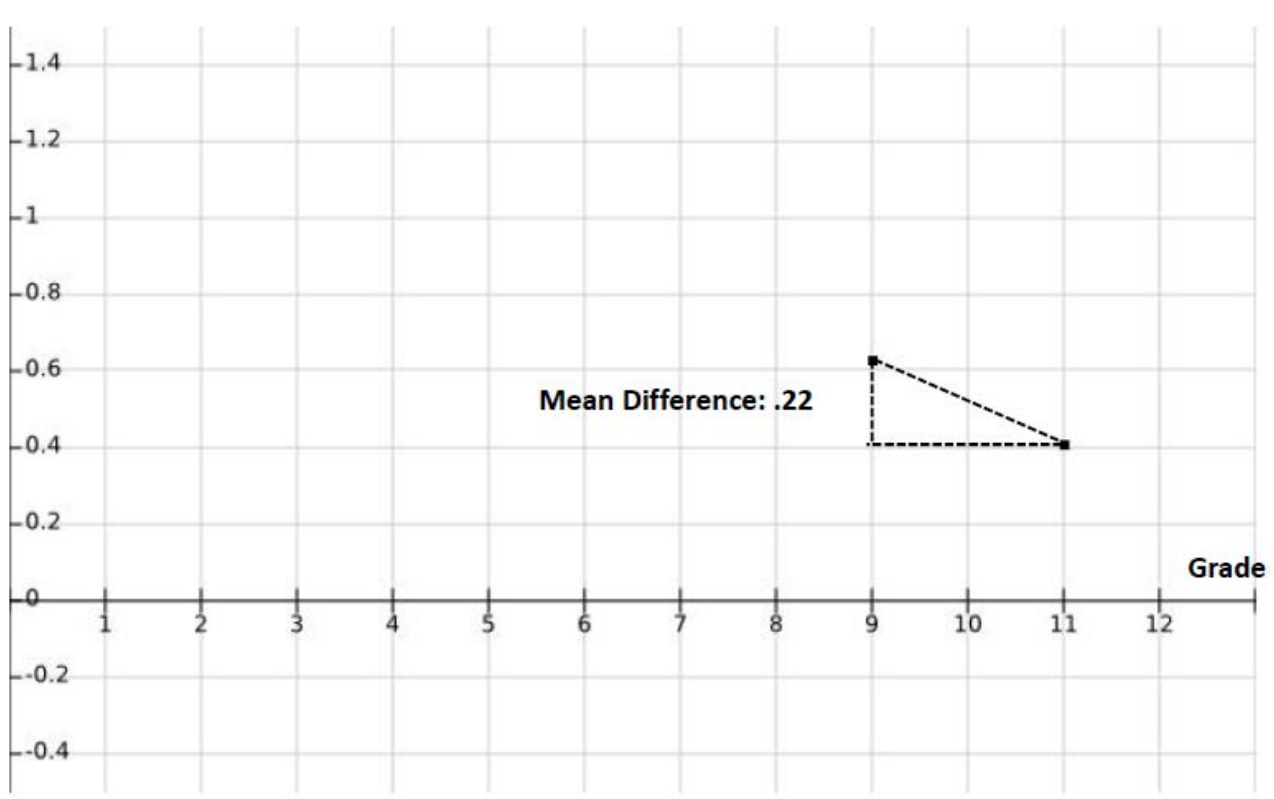

Ability Level

Figure 6. Ability level growth in scientific inquiry skills

\section{Parents' level of education on students' performance}

One way ANOVA was used to find out if parents level of education have significant influences on the children's performances. There was no statistically significant difference found between students whose mothers attained secondary education level and higher education level, as well as those whose mothers did not go to school, $\mathrm{p}>.05$. However, students whose mothers did not finish primary school, performed significantly better than whose mothers have reached secondary education and higher education level, $\mathrm{F}(4.189)=\mathrm{p}<.05$. Fathers have no significant influences on students' performances. Rasch model analysis was also used to indicate the effect of mothers' level of education on students' performance at each item (see table 6 and Figure 7).

Table 6, showing the parents' educational level

\begin{tabular}{l|ll|ll}
\hline & Mothers & Fathers & \\
\cline { 2 - 5 } & Frequency & Percentage \% & Frequency & Percentage \% \\
\hline Did not go to school & 3 & 2.5 & 4 & 3.4 \\
Did not finish primary school & 4 & 3.4 & 2 & 1.7 \\
Primary education & 10 & 8.5 & 7 & 5.9 \\
Secondary education & 56 & 47.5 & 36 & 30.5 \\
Higher education & 45 & 38.1 & 55 & 46.6 \\
PhD degree & - & - & 3 & 2.5 \\
I do not know & - & - & 11 & 9.3 \\
\hline Total & $\mathbf{1 1 8}$ & $\mathbf{1 0 0 . 0}$ & $\mathbf{1 1 8}$ & $\mathbf{1 0 0 . 0}$ \\
\hline
\end{tabular}




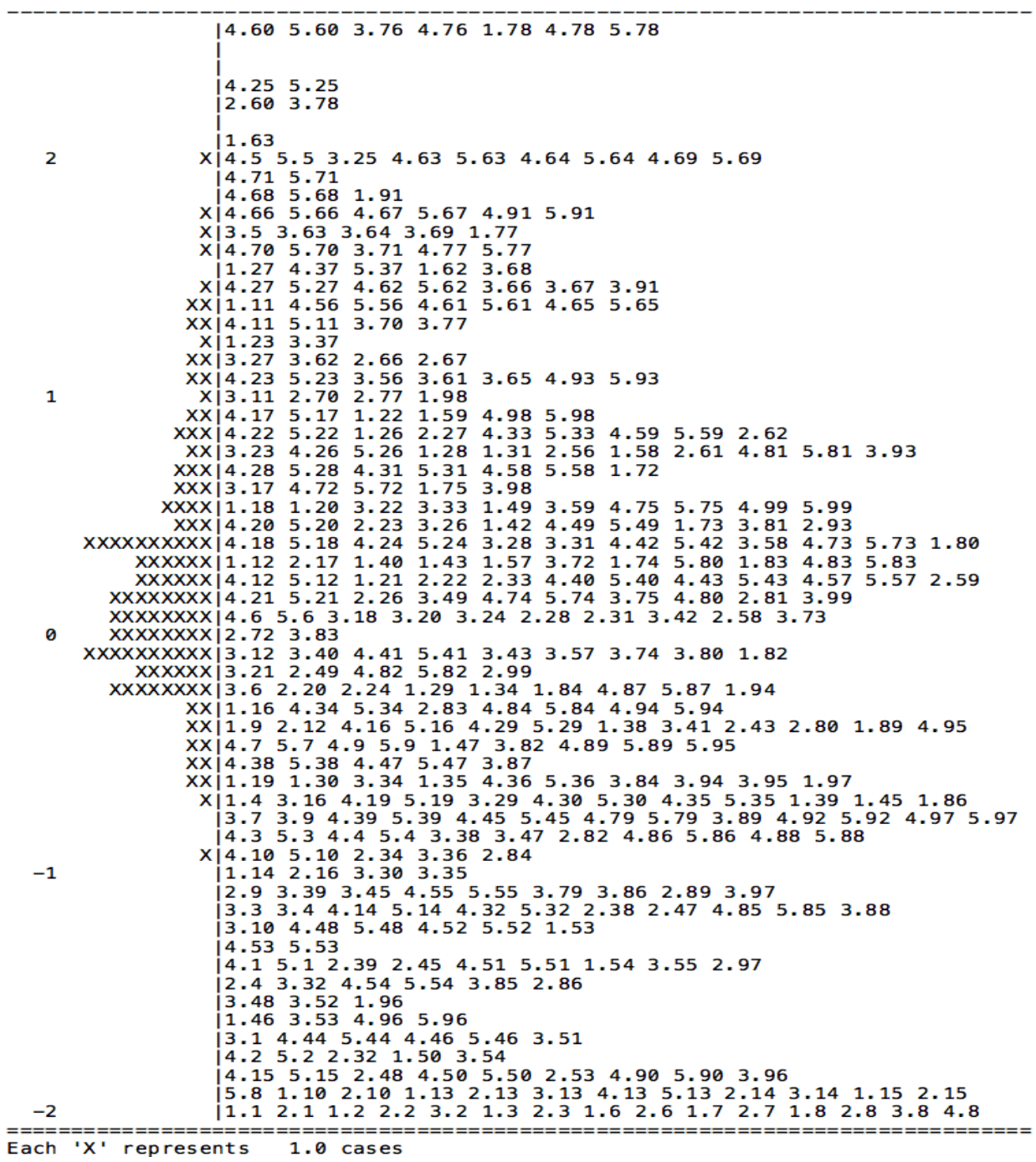

Figure 7. Effect of mothers' education level on students' performance on items

\section{Conclusion}

The online assessment instrument for scientific inquiry skills proved to be reliable regarding the whole test but at its subscales, only two (planning of variables and experimental plans) have high reliability, the remaining five subscale have internal consistency of $\leq .52$ Cronbach alpha. This means that, the items organizations at subscales level need to be relooked at. Regardless of that, research have indicated that advantages of technology-based assessment, such as online test administration and automatic calculation of scoring, reduced the time and cost of the testing process (Pasztor, Molnar \& Csapo, 2015). Considering these characteristics, the first steps to be 
undertaken is to make the instrument suitable for everyday school practice and for possible large-scale assessments in Namibia. The findings indicate that online assessment may provide teachers an easy-to-use instrument for monitoring the development of students' scientific inquiry skills and reasoning skills, and may contribute to the development of effective teaching and learning methods. The question yet to be answered is that, are the stakeholders in the education fraternity ready to improve the ICT infrastructures in most public schools as per their blueprint? (MoE, 20012006). From the personal experience of being a teacher in public schools for quite sometimes, it is recognized that not all public schools have reliable internet connectivity and functional ICT rooms. Schools that have ICT rooms, the internet connection may be either weak or no signals at all.

The correlations between the subscales proved to be significant. This means that with further development, the test could be used to effectively assess the abilities of students' scientific inquiry skills. Furthermore, students' mean performance was moderate but it could be improved with further training on scientific inquiry skills during the teaching and learning. One question that rose at the back of the mind was, do teaching and learning science in Namibia involve the enhancement and inculcating of the inquiry skills to students, as it is prescribed in the Namibian national syllabi for natural sciences subjects? Mean performances between the two grades and genders was not statistically significant different. With regard to genders differences, some science education researchers have reported that gender influenced students' understanding and their attitudes toward science (AlZoubi, El-shar'a, \& Al-Salam, 2009; Dimitrov, 1999; Lappan, 2000; Valamides, 1996). The study results conformed to other research that no significant difference was found in performance between genders. Recent research by (Piraksa, Srisawasdi \& Koul, 2013) indicated that gender does not significantly influence students' scientific reasoning ability. Therefore, the findings point to the fact that there is critical area for improvement of students' scientific inquiry skills and reasoning ability. This also implied that instructional pedagogy in science classroom should emphasize more on how to: (i) reason casually based on hypothesis generation, and (ii) design well thought science experiment, in order to enhance the development of students' scientific inquiry skills and reasoning ability.

There is consistent evidence that parents' education predicts children's educational outcomes, alongside other distal family characteristics such as family income, parents' occupations, and residence location (Eccles \& Davis-Kean, 2005). Other current research also echoed the same sentiments, e.g. significant positive relationship between parents' education level and academic achievements of students in India (Asad khan, Iqbal \& Tasneem, 2015). Interestingly, the results indicate the opposite. Students 
whose mothers did not finish primary education outperformed those students whose mothers have attained secondary and higher education levels. One explanation for this is that, in Namibia, children from low-income society tends to work harder than those from affluent society, because they want to come out of poverty level and live a better life. On the other hand, children of parents having better education do not seem to see the need to work hard, since they are provided with almost everything they want. However, this needs to be proven with scientific research in order to shed more light.

\section{Educational implications}

The items tested in this study could be used to assess students' abilities in scientific thinking and reasoning using inquiry methods. According to this diagnosis of students' abilities, specific learning environments can be created to promote students' inquiry skills. One goal of science education is to produce scientifically literate people with both content knowledge and knowledge of inquiry methods (Lederman and Lederman 2012), which is achievable. In school, content knowledge structured according to specific subject topics is not the only way of teaching science subjects, as this subjects-specific content knowledge could also be structured according to the inquiry methods. Because no method seems to be more complex for students at this age, teachers can choose the method that fits the topic well to foster the students' abilities in this inquiry method (Nowak et al., 2013).

\section{Limitations for the study}

Online assessment and computer usage might be new to most of the students in Namibia. Since they may not be familiar with technology-based assessment, this research instrument may not be able to give accurate ability and developmental level of the students. Another limitation is related to sample size in the current study. The sample is relatively small and do not represent average students within the country. Overall, in order to get accurate structure of scientific inquiry skills and provide better explanations, a paper and pencils approach may be employed in future studies with larger sample from different region across Namibia. Such an approach can help determine students' ability and developmental level of scientific inquiry, and the differences between regions could be determined.

\section{Acknowledgements}

The author of the paper is on; Stipendium Hungaricum Scholarship program and the Namibian government financial support (Namibia Students Financial Assistance Fund, NSFAF). 


\section{References}

Al-Zoubi, T., El-shar'a, I., \& Al-Salam, M. K. (2009). The Scientific Reasoning Level of Students' In the Faculty of Science In Al-Hussein Bin Talal University and Its Affection of Gender, Teaching level, and Specialization. An-Najah University Journal for Research - Humanities, 23(2), 401-437.

American Association for the Advancement of Science (1993). Benchmarks for Science Literacy. New York: Oxford University Press.

Asad khan, R. M., Iqbal, M., \& Tasneem, S. (2015). The influence of parents' educational level on secondary school students' academic achievements in district Rajanpur, Journal of Education and Practice, 6 (16), 76-79.

Bao, L., \& Koenig, K. (2012). TI21: A Technology Enhanced Inquiry Framework for Developing and Assessing 21st Century Skills, iSTARAssessment.org.

Binkley, M., Erstad, O., Herman, J., Raizen, S., Ripley, M., \& Rumble, M. (2010). Defining 21st century skills. Retrieved from http://atc21s.org/wpcontent/uploads/2017/03/25-Defining-21st-Century-Skills.pdf.

Bybee, R. W. (2009). The BSCS 5E Instructional Model and 21st Century Skills. National Academies Board on Science Education, Washington, DC: Retrieved March 20, 2017. from: https://www7.nationalacademies.org/bose/1Bybee_21st\%20Century_Paper.p df.

Capps, D. K., \& Crawford, B. A. (2013). Inquiry-based instruction and teaching about nature of science: Are they happening? Journal of Science Teacher Education, 24, 497-526.

Chinn, C. A., \& Malhotra, B. A. (2002). Epistemologically authentic inquiry in schools: A theoretical framework for evaluating inquiry tasks. Science Education, 86, 175-218.

Csapo, B. (1997). Development of inductive reasoning: Cross-sectional measurements in an educational context. International Journal Behavioural Development. 20(4). 609-625.

Csapó, B., Lorincz, A., \& Molnár, G. (2012). Innovative assessment technologies in educational games designed for young students. In D. Ifenthaler, D. Eseryel \& X. Ge (Eds.), Assessment in game-based learning: foundations, innovations, and perspectives (pp. 235-254). New York: Springer.

Csapó, B. and Funke, J. (eds.) (2017), The Nature of Problem Solving: Using Research to Inspire 21st Century Learning, OECD Publishing, Paris. http://dx.doi.org/10.1787/9789264273955 
Dimitrov, D. M. (1999). Gender differences in Science Achievement: Differential Effect of Ability, Response Format, and Stans of Learning Outcomes. School Science and Mathematics, 99(8), 445-450.

Eccles, J. S. and Davis-Kean, P. E. (2005). Influence of parents' education on their children' educational attainments: the role of parent and child perceptions. London Review of Education, 3(3), 191-204.

Fenichel, M., \& Schweingruber, H. (2010). Surrounded by science: Learning science in informal environments. Washington, D. C.: National Press.

Gaigher, E., Lederman, N., \& Lederman, J. S. (2014). Knowledge about Inquiry: A study in South African high schools, International Journal of Science Education, 36(18), 3125-3147.

Gilbert, J. K., Pietrocola, M., Zylbersztajn, A. and Franco, C. (2000). Science and Education, Notions of Reality, Theory and Models. In Developing Models in Science Education, edited by Gilbert, J. K and Boulter, C. J. 19-40. Dordrecht: Kluwer.

Gott, R., \& Duggan, S. (1998). Understanding Scientific Evidence - Why it Matters and How It Can Be Taught. In M. Ratcliffe (Ed), ASE (The Association for Science Education) Guide to Secondary Science Education, (pp. 92-99). Cheltenham: Stanley Thornes.

Gott, R., and Duggan. S. (1995). Investigative work in the science curriculum. Buckingham: Open University Press.

Hammann, M., Phan, T. T. H., Ehmer., M., \& Grimm, T. (2008). Assessing Pupils' Skills in Experimentation. Journal of Biological Education 42 (2): 66-72.

Klahr, D. (2000) Exploring Science: The Cognition and Development of Discovery Processes. Cambridge, MA: MIT Press.

Lappan, G. (2000). A Vision of Learning to teach for the 21st Century. School Science and Mathematics, 100(6), 319-325.

Lederman, N., \& Lederman, J. (2012). Nature of scientific knowledge and scientific inquiry. In B. J. Fraser, K. Tobin, \& C. J. McRobbie (Eds.), Second international handbook of science education (pp. 335-359). Dordrecht: Springer.

Mayer, J. (2007). Inquiry as Scientific Problem Solving. In D. Kruger \& H. Vogt (Eds). Theories in Biology Didactic, (pp.177-186). Heidelberg: Springer.

Ministry of Basic Education, Sport and Culture,. (2001). ICT policy for education. Windhoek: Polytechnic Press.

Ministry of Education. (2007). Education and training sector and Improvement program. Windhoek: Government Press.

Ministry of Education. (2009). Physical Science Syllabus Grades 8-10. Okahandja: NIED. 
Ministry of Education. (2010). National Curriculum for Basic Education. Okahandja: NIED.

Molnar, G., Greiff, S., \& Csapo, B. (2013). Inductive reasoning, domain specific and complex problem solving: relation and development. Thinking skills and Creativity, 9(8), 35-45.

Nagy, L.-né., Korom, E., Pásztor, A., Veres, G., \& B. Németh, M. (2015). A természettudományos gondolkodás online diagnosztikus értékelése [Online diagnostic assessment of scientific reasoning]. In B. Csapó, E. Korom, \& Gy. Molnár (Eds.), A természettudományi tudás online diagnosztikus értékelésének tartalmi keretei [Framework for the online assessment of scientific reasoning] (pp. 35-116). Budapest: Oktatáskutató és Fejlesztő Intézet.

National Research Council. (1996). National Science Education Standards. Washington, DC: National Academies Press.

National Research Council. (2012). A framework for K-12 science education: Practices, crosscutting concepts and core ideas. Washington, DC: National Academy Press.

Nowak, K. H., Nehring, A., Tiemann, R., \& Upmeier zu Belzen, A. (2013) Assessing students' abilities in processes of scientific inquiry in biology using a paper-and-pencil test, Journal of Biological Education, 47(3), 182188

Padilla, M. (1990). The Science Process Skills. Paper presented at the annual meeting of the National Association for Research in Science Teaching, French Lick, IN.

Pásztor, A., Molnár, Gy., \& Csapó, B. (2015). Technology-based assessment of creativity in educational context: the case of divergent thinking and its relation to mathematical achievement, Thinking skills and Creativity, 18, 3242.

Piraksaa, C., Srisawasdi, N., \& Koul, R. (2014). Effect of gender on students' scientific reasoning ability: a case study in Thailand, Procedia Social and Behavioral Sciences 116, 486 - 491.

Senler, B. (2015). Middle school students' views of scientific inquiry: An international comparative study Science Education International, 26(2), 166179

Schwartz, R. S., Lederman, N., \& Lederman, N. (2008, March). An instrument to assess views of scientific inquiry: The VOSI questionnaire. Paper presented at the international conference of the National Association for Research in Science Teaching. Baltimore, MD.

Simasiku, L., Kasanda, C. \& Smit, T. (2015). Teaching subjects matter through English as the Medium of instruction in the Namibian English second language classrooms, European Scientific Journal Special edition, vol.1 ISSN: 1857 - 7881 (Print) e - ISSN 1857- 7431 
Valamides, N. C. (1996). Formal Reasoning and Science Teaching. School Science and Mathematics, 96(2), 99-107.

Wenning, C. J. (2007). Assessing inquiry skills as a component of scientific literacy. Journal of Physics Teacher Education Online, 4(2), 21-24.

Yeh, Y., Jen, T., \& Hsu, Y. (2012). Major strands in scientific inquiry through cluster analysis of research abstracts. International Journal of Science Education, 34, 2811-2842.

Zimmerman, C. (2005). The Development of Scientific Reasoning Skills: What Psychologists Contribute to an Understanding of Elementary Science Learning. 